\title{
Design, Simulation, and Experimental Study of a Droplet-Based PCR by EWOD
}

\author{
Kessararat Ugsornrat*, Nitin V. Afzulpurkar, \\ Anurat Wisitsoraat ${ }^{1}$ and Adisorn Tuantranont ${ }^{1}$ \\ School of Engineering and Technology, Asian Institute of Technology, \\ Klong Luang, Pathumthani 12120, Thailand \\ ${ }^{1}$ Nanoelectronics and MEMS Laboratory, National Electronics and Computer Technology Center, \\ Klong Luang, Pathumtani 12120, Thailand
}

(Received March 26, 2009; accepted November 6, 2009)

Key words: polymerase chain reaction (PCR), electrowetting on dielectric (EWOD), droplet, finite element analysis

In this paper, a droplet-based polymerase chain reaction (PCR) with electrowetting on a dielectric (EWOD) is developed to focus on minimizing reagent consumption without the use of a mechanical mechanism to move the sample in the system. The dropletbased PCR system consists of a parallel-plate EWOD microchannel and serpentine-shape microheaters integrated underneath to maintain temperature for denaturation, annealing, and extension. Silicone oil is introduced at the bottom of the microchannel to reduce the temperature impact from control electrodes, prevent evaporation, and increase the contact angle reduction of droplets. The EWOD actuation is used to control the droplet in a PCR system. The EWOD configuration and serpentine-shape microheaters are designed on the basis of theoretical calculation and finite element (FEM) simulation. The simulation results indicate that the applied voltage of control electrodes does not affect the temperature of the microchannel. In addition, the optimized applied voltages of three microheaters for the temperature of PCR are 1.08, 0.57, and $0.91 \mathrm{~V}$. The contact angle characterization shows a significant increase in contact angle reduction by silicone oil application. Moreover, the use of silicone oil allows a higher applied voltage for transporting a droplet without evaporation. The thermal characterization of the PCR microchannel shows that the temperature of microheaters is in good agreement with the simulation. Moreover, the PCR experiment in the droplet-based PCR chip confirms a successful DNA amplification.

\section{Introduction}

Polymerase chain reaction (PCR) is a powerful technique of amplifying DNA through repetitive temperature cycling. The temperatures used in PCR are typically 90 $94^{\circ} \mathrm{C}$ for denaturation of double-stranded DNA, $50-70^{\circ} \mathrm{C}$ for annealing, and $70-75^{\circ} \mathrm{C}$ for

${ }^{*}$ Corresponding author: e-mail: Kessararat.Ugsornrat@ait.ac.th 
extension of an oligonucleotide primer. PCR can be applied in medical and other related fields because its output can produce sufficient amounts of DNA of interest for detection and analysis. ${ }^{(1)}$

A miniaturized PCR device has many advantages over a conventional PCR system, including shorter cycle time, portability, smaller PCR reagent volume, and ease of integration with a DNA detection system. In general, PCR systems follow two basic approaches. The first kind is a stationary thermocycling PCR device, which utilizes a reaction chamber with direct heating, ${ }^{(2-4)}$ IR heating, ${ }^{(5)}$ and convectional heat transfer. ${ }^{(6)}$ The other type is a flow-through system, which involves continuous flow ${ }^{(7-9)}$ and dropletbased micro-oscillating flow PCRs. ${ }^{(10,11)}$ Flow-through systems are preferred over stationary ones because of a faster reaction process. Among flow-through PCR systems, droplet-based PCR is particularly attractive because it requires a minimal volume of PCR reagents. However, a droplet-based PCR system requires a special mechanism to move the sample among three constant temperature zones. ${ }^{(10)}$

Electrowetting on dielectric (EWOD) is a well-known method of modifying the wetting properties of liquid droplets by applying an external electric potential. The electric potential causes a change in the contact angle of a droplet, leading to droplet deformation and movement. ${ }^{(12-20)}$ The EWOD mechanism allows fluid movement with no mechanical drive, so the EWOD device would have a much longer lifetime than others that use mechanical actuation. Other advantages of EWOD devices include ease of fabrication, simple control signal, digital operation, programming flexibility, and minimal fluid consumption.

However, there are some problems associated with this technique, including high voltage requirement, unsteady fluid flow, contact angle hysteresis, fluid evaporation, temperature nonuniformity, and electrolysis. Recently, oil application has been reported to be an effective method to reduce the droplet driving voltage, contact angle hysteresis, unsteady motion, fluid evaporation, and electrolysis. ${ }^{(21-23)}$ Moreover, the temperature distribution in the reaction microchannel of a droplet PCR device with the serpentineshape microheater has been studied.(24)

In this work, a droplet-based PCR chip with an integrated EWOD device is designed, fabricated, and characterized with silicone oil applied at the bottom of the microchannel. First, the EWOD configuration and serpentine-shape microheaters are designed on the basis of theoretical calculation and finite element (FEM) simulation. Next, the PCR chip is fabricated by thin-film deposition and micromolding processes. Finally, the device is characterized by contact angle analysis, evaporation testing, microheater measurement, and PCR experiment with a specific DNA.

\section{Design of a Droplet-Based PCR with EWOD}

\subsection{Design of EWOD}

The EWOD configuration used in the droplet-based PCR chip is designed on the basis of the work of Moon et al. ${ }^{(25)}$ A minimum required voltage for EWOD operation is then estimated using the Lippmann-Young equation: 


$$
\cos \theta=\cos \theta_{0}+\frac{1}{2} \frac{C}{\gamma_{\mathrm{LG}}} V^{2}
$$

where $\theta$ is the contact angle with an applied potential, $\theta_{0}$ is the contact angle with no applied potential, $\gamma_{\mathrm{LG}}$ is the surface tension at the liquid-gas interface, $t$ is the thickness of insulating layers, $V$ is the applied voltage, and $C$ is the capacitance of the dielectric layer. The contact angle difference $\left(\theta-\theta_{0}\right)$ is restricted to be no more than $40^{\circ}$ by contact angle saturation. $\gamma_{\mathrm{LG}}$ is $0.072 \mathrm{~N} / \mathrm{m}$ for water. The total capacitance of $\mathrm{SiO}_{2}$ and Teflon ${ }^{\circledR} \mathrm{AF}$ insulating layers in the design is determined to be $2.46 \times 10^{-4} \mathrm{~F} / \mathrm{m}^{2}$.

From eq. (1), the minimum required voltage $V$ for droplet actuation with a contact angle change from $120^{\circ}$ to $80^{\circ}$ is calculated to be $19.86 \mathrm{~V}$. The required channel gap for splitting a droplet is then determined from the following equation:(26)

$$
\frac{1}{R_{1}}=\frac{1}{R_{2}}-\frac{\varepsilon_{0} \varepsilon V^{2}}{2 \gamma_{\mathrm{LG}} d t}
$$

where $R_{1}$ and $R_{2}$ are the radii of curvature of EWOD electrodes and $d$ is the channel gap of the EWOD structure.

In this design, $V=19.86 \mathrm{~V}, R_{2}=0.5 \mathrm{~mm}$, and $R_{1}=-0.5 \mathrm{~mm}$ (half size of the control electrode); the required channel gap ( $d$ ) for splitting a droplet is estimated from eq. (2) to be $0.1684 \mathrm{~mm}$. Thus, the channel gap for droplet splitting has to be less than 0.1684 $\mathrm{mm}$.

Next, the capillary pressure difference between two sides of a droplet is determined from the following equations: ${ }^{(26)}$

$$
\begin{gathered}
\Delta P=\frac{\gamma_{L G}}{d}\left(\cos \theta_{11}-\cos \theta_{1 \mathrm{l}}\right), \\
\Delta P=\frac{C V^{2}}{2 d},
\end{gathered}
$$

where $\theta_{\mathrm{ll}}$ and $\theta_{\mathrm{lr}}$ are contact angles of the droplet in the left and the right of the wall bottom, respectively (The droplet is moving to the left side). In this design $d=0.16 \mathrm{~mm}$; the capillary pressure difference between two sides of the droplet when the contact angle changes from $120^{\circ}$ to $80^{\circ}$ is then determined from eq. (3) to be $0.3 \times 10^{3} \mathrm{~N} / \mathrm{m}^{2}$. By using the calculated pressure difference, the driving voltage for transporting a droplet is solved from eq. (4) to be $19.86 \mathrm{~V}$, which turns out to be the same as the minimum voltage for droplet actuation when the contact angle changes from $120^{\circ}$ to $80^{\circ}$.

\subsection{Design of droplet-based PCR system}

The droplet-based PCR with EWOD is developed to focus on minimizing reagent consumption without the use of a mechanical mechanism to move the sample in the system. As illustrated in Fig. 1, the EWOD-based PCR system consists of 3.2-mm-wide 


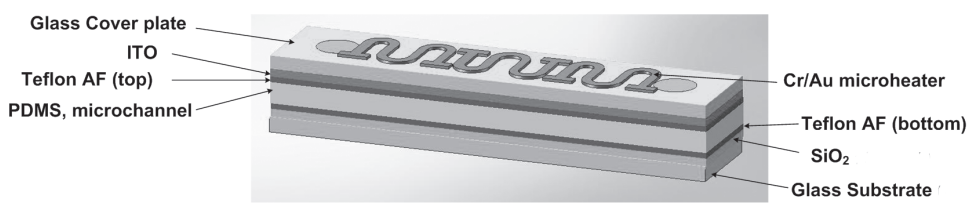

(a)

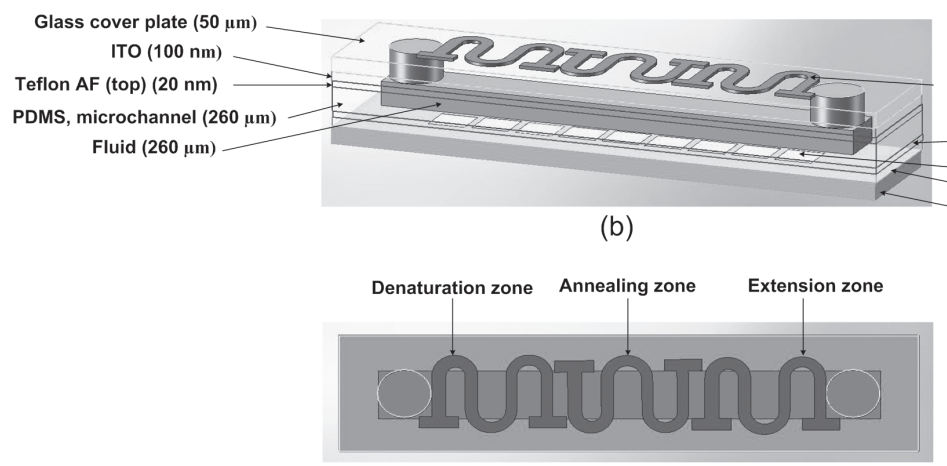

(c)

Fig. 1. Droplet-based PCR model (a) 3D representation, (b) transparent view, and (c) top view.

and 14.8-mm-long serpentine-shape microheaters and a $0.26-\mathrm{mm}$-deep microchannel. The microchannel is designed to be a single straight line with a depth of $0.26 \mathrm{~mm}$. The electrode gaps are set to be $1.0 \mathrm{~mm}$. The droplet will be driven between square electrodes (dimension $1 \times 1 \mathrm{~mm}^{2}$ ) that maintain temperatures for denaturation, annealing, and extension.

The system utilizes silicone oil application in the microchannel in order to reduce heat transfer from control electrodes, decrease contact angle, and minimize droplet evaporation. A $0.1-\mathrm{mm}$-thick layer of $1 \mathrm{cSt}$ silicone oil is applied at the bottom of the channel. As a result, the height of the air space in the microchannel for the PCR reaction is $0.16 \mathrm{~mm}$. The droplet will be splitting from the reservoir and transported back and forth along the microchannel by EWOD actuation. A droplet is first held onto one electrode with an applied voltage. It is then transported to the nearest electrode by deactivating this electrode and activating the nearest one. For a droplet-based PCR, microheaters are integrated on top of the EWOD device to support the temperature zones of PCR. Three serpentine-shape microheaters are maintained at 90,60 , and $72^{\circ} \mathrm{C}$ for denaturation, annealing, and extension, respectively.

\subsection{Simulation of microheater for PCR system}

The thermal characteristics of the PCR system are designed and simulated using CoventorWare $^{\circledR}$, which is a FEM simulation tool from Coventor Inc. The electrothermal solver (Etherm) module is used to simulate the temperature distribution of PCR. This solver is used to compute the thermal and electrical potential field distributions resulting from an applied voltage. A 2D layout is used to build a 3D solid model for meshing 
and simulation. The thermal distribution is simulated for the systems with and without silicone oil.

Firstly, an electrical potential is applied only to the control electrode. Surface boundary conditions are set by specifying the voltage on two pads of the control electrode, and the temperature distribution of the PCR microchannel is analyzed. Secondly, an electrical potential is applied only to three microheaters. Surface boundary conditions are set on six pads of microheaters. The temperature distributions of the microheaters at various applied voltages are then analyzed. Heaters 1, 2, and 3 in Fig. 1 are areas of denaturation, annealing, and extension, respectively. The applied voltages for these microheaters to obtain the correct temperature for the PCR process are determined from the simulation.

\section{Fabrication of a Droplet-Based PCR with EWOD}

The droplet-based PCR structure consists of two main parts: a parallel-plate EWOD device and serpentine-shape microheaters on the back surface of the glass cover plate, as shown in Fig. 2.

The EWOD device consists of two parallel glass plates and an intermediate PDMS microfluidic slab. The thickness of the PDMS layer is used to define the gap between the top and bottom plates in the parallel-plate structure. On the bottom plate, a nineterminal linear array of $100-\mathrm{nm}$-thick $\mathrm{Cr} / \mathrm{Au}$ electrodes is deposited on the glass substrate by sputtering. $\mathrm{Cr} / \mathrm{Au}$ thin films are sputtered at $0.2 \mathrm{~mA} \mathrm{DC}$ current, while the glass substrate is covered with a predesigned microshadow mask to obtain electrode patterns. The 30-nm-thick Cr layer is used as an adhesive layer between a 70-nm-thick Au layer and a glass substrate.

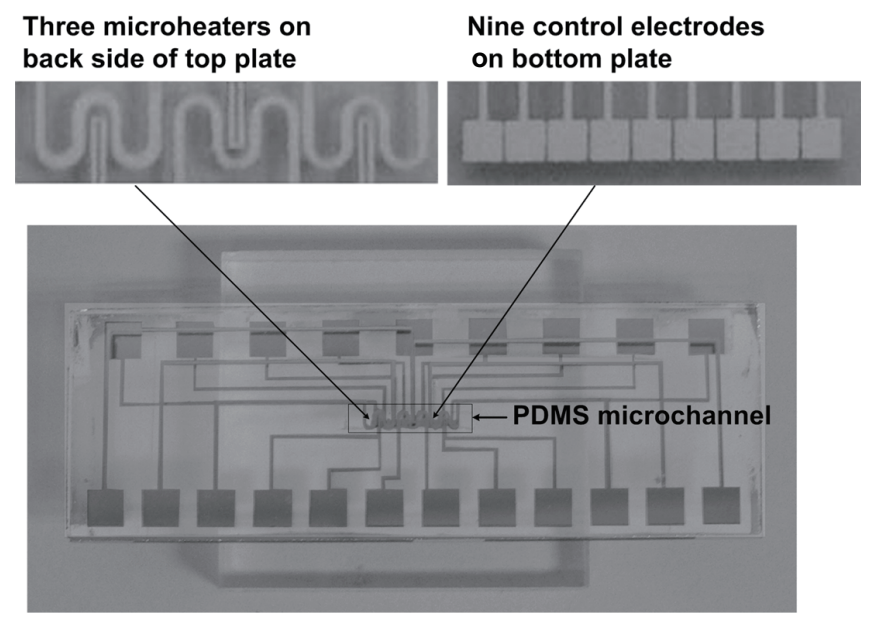

Fig. 2. Droplet-based PCR device with integrated $\mathrm{Cr} / \mathrm{Au}$ heater/temperature sensors: the PCR chip consists of two substrates (top plate and bottom plate) and PDMS microfluidic channel. 
A 100 -nm-thick silicon dioxide dielectric layer is then deposited on the $\mathrm{Cr} / \mathrm{Au}$ thin films by reactive radio frequency (rf) sputtering at $100 \mathrm{~W}$ r.f. power for $50 \mathrm{~min}$. Next, a 20-nm-thick hydrophobic Teflon ${ }^{\circledR}$ AF 1601 (Dupont, USA) layer is spin-coated on the silicon dioxide layer at a spinning speed of $6000 \mathrm{rpm}$ (revolutions per minute) for $30 \mathrm{~s}$. It is then maintained at ambient temperature for around 15-20 min before baking at 110 ${ }^{\circ} \mathrm{C}$ for $15 \mathrm{~min}, 160^{\circ} \mathrm{C}$ for $15 \mathrm{~min}$, and $330^{\circ} \mathrm{C}$ for $30 \mathrm{~min}$.

On the top cover glass plate, the entire area is coated with a transparent and conductive indium tin oxide (ITO) film by evaporation. The $15 \Omega /$ square ITO thin film is thermally evaporated on the glass cover plate at an evaporation rate of $15 \mathrm{~nm} / \mathrm{s}$. Then, a 20-nm-thick Teflon ${ }^{\circledR}$ AF layer is spin-coated on the ITO-covered top cover glass. On the back surface of the glass cover plate, 100 -nm-thick $\mathrm{Cr} / \mathrm{Au}$ thin films for microheater and temperature sensor are deposited by sputtering through another microshadow mask under the same condition as that for EWOD electrodes.

The PDMS slab with microchannels is then fabricated by casting the micromold with PDMS containing precursor. The PDMS source is Sylgard 184 Silicone Elastomer kit (Dow Corning), consisting of PDMS. To prepare the material for casting, the PDMS sylgard precursor is mixed with a curing agent at a ratio of 10:1 by volume. PDMS mixtures are gradually poured onto the SU8 master mold to the height over the depth of the designed channels. The PDMS slab is then cured at $100^{\circ} \mathrm{C}$ for $30 \mathrm{~min}$ on an SU-8 mold. The molded PDMS slab is finally peeled off from the mold.

Since the PDMS surface is naturally hydrophobic, surface modification is required for glass bonding. In order to perform bonding and make a hydrophilic surface, PDMS and the glass surface are subjected to oxygen plasma treatment at $100 \mathrm{~W}$ r.f. power for 5 min in a commercial oxygen plasma system. After oxygen plasma treatment, PDMS and two glass plates are immediately brought into contact to form bonding.

\section{Experimental Methods}

\subsection{Contact angle measurement and evaporation testing}

The Contact angle of a droplet is determined by side-view image analysis using a contact angle measurement system (ramé-hart Instrument Co. model 200). The droplet contact angle changes under applied voltages on EWOD electrodes have been characterized for different fluids, including deionized water, $0.1 \mathrm{M} \mathrm{KCl}$ solution, and PCR reagent $(10 \times$ Taq polymerase buffer consisting of $750 \mathrm{mM}$ Tris- $\mathrm{HCl}(\mathrm{pH} 8.8$ at 25 $\left.{ }^{\circ} \mathrm{C}\right), 200 \mathrm{mM}\left(\mathrm{NH}_{4}\right)_{2} \mathrm{SO}_{4}, 0.1 \%$ Tween 20 , and $1.5 \mathrm{mM} \mathrm{MgCl}_{2}$ ). Moreover, the droplet evaporation in the microchannel under different applied voltages is also observed and recorded through the microscope of the contact angle measurement system.

In the experiment, a $0.7 \mu \mathrm{l}$ droplet is inserted into the microchannel and the contact angle is measured under different conditions. In particular, the effect of a $0.1-\mathrm{mm}-$ thick silicone oil filled at the bottom of the microchannel on the droplet contact angle is characterized under different applied voltages.

\subsection{Temperature measurement}

The thin-film $\mathrm{Cr} / \mathrm{Au}$ temperature sensors on the back surface of a top cover plate are calibrated before they can be used for temperature measurement. The resistances of 
the gold temperature sensors at various temperatures are measured and plotted. A leastsquares method is then used to obtain the best fit linear equation line for the temperature sensor characteristic. This equation will give the relationship between the resistance and temperature of the $\mathrm{Cr} / \mathrm{Au}$ temperature sensors. The temperatures of three microheaters can then be measured using the calibrated temperature sensor.

\subsection{Experimental setup for EWOD}

A droplet is initially placed and inserted in the gap between the substrate and glass cover plate on the center of a grounded electrode. The applied potential on the adjacent electrode is increased until motion is observed. A low-voltage operation is controlled using a conventional electronic circuit, a power supply, and the activation signals switched by a computer program. The details of the experiment and working mechanism of the device are found in the work of Cho et al..$^{(27)}$

\subsection{A droplet-based PCR experiment}

The DNA template with $500 \mathrm{ng} / \mu \mathrm{l}$ concentration is used as the starting DNA for PCR amplification. The sequences of the forward and reverse primers used for DNA segmentation are 5'-GGTATCGAGTTCATTTTGGGGTG-3' and 5'-GATGATCTT GGAGCATTCCCA C-3', respectively. The final volume of $25 \mu \mathrm{l}$ of the PCR mixture contains $14.1 \mu \mathrm{l}$ of sterile distilled water, $2.5 \mu \mathrm{l}$ of $10 \times$ PCR buffer, $1.3 \mu \mathrm{l}$ of $1.5 \mathrm{mM}$ $\mathrm{MgCl}_{2}, 2 \mu \mathrm{l}$ of $2 \mathrm{mM}$ deoxynucleoside triphosphate dNTP mix (dATP, dTTP, dCTP, dGTP), $2 \mu \mathrm{l}$ of 10 pmol forward and reverse primers, $1 \mu \mathrm{l}$ of DNA template sample, and 0.1 $\mu \mathrm{l}$ of $5 \mathrm{U} / \mu \mathrm{l}$ Taq polymerase.

The microheater and temperature sensors are used to control the temperature inside the microchannel at desired PCR temperatures. The PCR mixture is driven in the microchannel for 35 thermal cycles. The PCR reaction starts with $3 \mathrm{~min}$ at $94^{\circ} \mathrm{C}$ for predenaturation, followed by 35 cycles of $30 \mathrm{~s}$ denaturation at $94^{\circ} \mathrm{C}, 30 \mathrm{~s}$ annealing at $60^{\circ} \mathrm{C}$, and $3 \mathrm{~min}$ extension at $72^{\circ} \mathrm{C}$, and ends with $3 \mathrm{~min}$ at $72^{\circ} \mathrm{C}$ for final extension. The PCR products are analyzed by gel electrophoresis. The gel is stained with ethidium bromide solution for $10 \mathrm{~min}$ and then destained with decolorized solution for $10 \mathrm{~min}$. The separation of DNA bands of the PCR product is visualized using a UV transilluminator and compared with a $100 \mathrm{bp}$ DNA marker for determination of DNA size.

\section{Results and Discussion}

\subsection{Simulated thermal analysis of a droplet-based PCR}

Figure 3 shows the simulated temperature distribution of fluid in the microchannel with $1 \mathrm{cSt}$ silicone oil when an electrical potential is applied only to the control EWOD electrode. It shows the significant temperature difference for the case with silicone oil. The air region will be the volume for PCR processing. It can be seen that the air region is at room temperature when there is no electric potential applied to the three microheaters. The simulation result confirms that the applied EWOD voltage for moving the droplet does not affect the temperature of the microchannel. Therefore, the temperature of the 


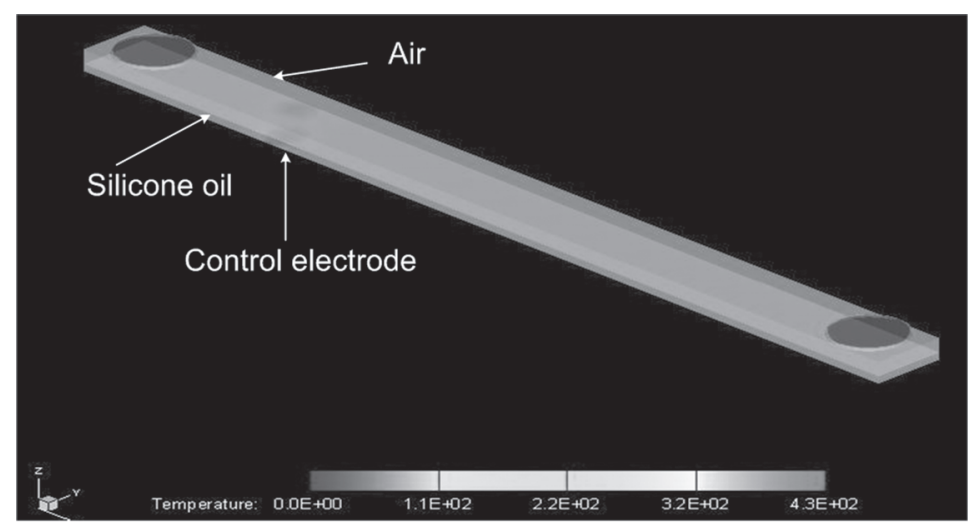

Fig. 3. Temperature distribution of PCR fluid microchannel with voltages applied only to control electrodes. The gray bar indicates $300 \mathrm{~K}$ (room temperature).

microchannel is controlled only by three microheaters.

Thermal simulation is performed to analyze the thermal distribution of the dropletbased PCR when an electrical potential is applied only to three microheaters. The simulation results are shown in Fig. 4 and Table 1. From the results, the appropriate microheater voltages for the required PCR temperatures of $91.25,62.03$, and $72.67^{\circ} \mathrm{C}$ are $1.08,0.57$, and $0.91 \mathrm{~V}$, respectively. The table also gives the standard deviation (S.D.) of temperature variation for microheaters at different tempertures. It is clear that the maximum temperature variation is only slightly more than $1{ }^{\circ} \mathrm{C}$ for all the temperatures. The results demonstrate that the shape and dimension of the microheaters are properly designed.

Figures 5(a) and 5(b) show the temperature distribution of the EWOD dropletbased PCR system in the regions of microheaters and microchannel, respectively. The temperature distribution of underlying microheaters in Fig. 5(a) can be shown by making the microchannel, inlet, and outlet transparent (in the simulation display). It can be seen that the temperatures in each zone of the microheaters are fairly uniform, while there are slightly higher temperature variations over PCR microchannels. From Figs. $5(\mathrm{a})$ and 5(b), the maximum temperature differences between the PCR microheaters and microchannels are less than $0.5^{\circ} \mathrm{C}$. Tables $2-4$ list the simulated maximum temperature value at microheaters and microchannels under different sets of operating voltages. It can be seen that the temperature of the microchannel is almost the same as that of the microheater. Therefore, the temperatures of the three microheaters can be very good representatives for that of the PCR sample in microchannels.

\subsection{Experimental results of a droplet-based PCR}

\subsubsection{Contact angle analysis}

Schematics of the experimental setup for contact angle reduction measurement and evaporation observation are shown in Fig. 6(a). Figures 6(b)-6(d) show contact angle 


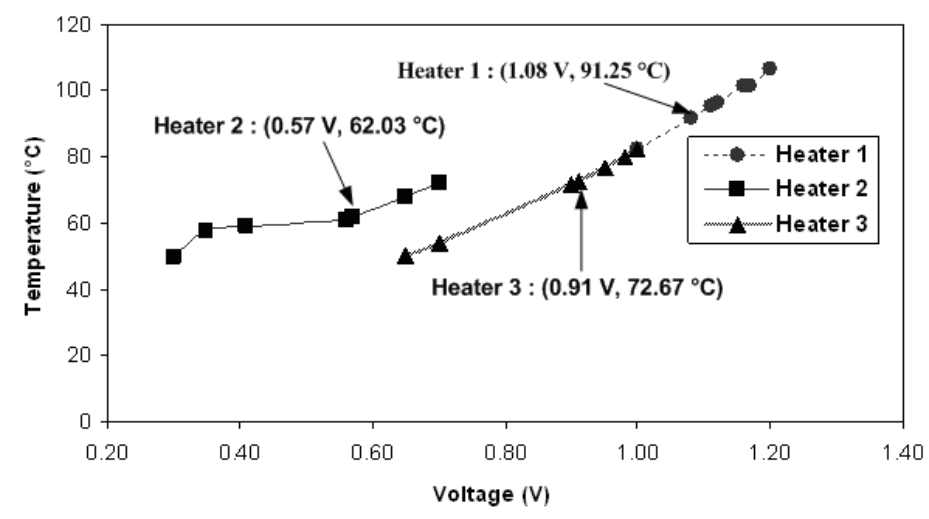

Fig. 4. Temperature vs applied voltage to three microheaters of a droplet-based PCR.

Table 1

Temperature vs applied voltage for three microheaters of an EWOD-droplet based PCR.

\begin{tabular}{cccccccccc}
\hline \multirow{3}{*}{ Data } & \multicolumn{3}{c}{ Heater 1 } & \multicolumn{3}{c}{ Heater 2 } \\
\cline { 2 - 9 } & $\begin{array}{c}\text { Voltage } \\
(\mathrm{V})\end{array}$ & $\begin{array}{c}T_{\max } \\
\left({ }^{\circ} \mathrm{C}\right)\end{array}$ & $\begin{array}{c}\text { S.D. } \\
\left({ }^{\circ} \mathrm{C}\right)\end{array}$ & $\begin{array}{c}\text { Voltage } \\
(\mathrm{V})\end{array}$ & $\begin{array}{c}T_{\max } \\
\left({ }^{\circ} \mathrm{C}\right)\end{array}$ & $\begin{array}{c}\text { S.D. } \\
\left({ }^{\circ} \mathrm{C}\right)\end{array}$ & $\begin{array}{c}\text { Voltage } \\
(\mathrm{V})\end{array}$ & $\begin{array}{c}T_{\max } \\
\left({ }^{\circ} \mathrm{C}\right)\end{array}$ & $\begin{array}{c}\text { S.D. } \\
\left({ }^{\circ} \mathrm{C}\right)\end{array}$ \\
\hline 1 & 1.00 & 82.22 & 1.13 & 0.30 & 49.91 & 1.22 & 0.65 & 50.25 & 0.60 \\
2 & 1.17 & 101.35 & 0.86 & 0.35 & 57.60 & 0.60 & 0.70 & 54.14 & 0.52 \\
3 & 1.12 & 96.27 & 0.86 & 0.41 & 59.02 & 0.54 & 0.90 & 71.58 & 0.68 \\
4 & 1.11 & 95.17 & 0.58 & 0.56 & 61.10 & 0.59 & 0.95 & 77.64 & 0.50 \\
5 & 1.08 & 91.25 & 0.93 & 0.57 & 62.03 & 0.47 & 0.91 & 72.67 & 0.85 \\
6 & 1.16 & 101.46 & 0.55 & 0.65 & 67.93 & 0.10 & 0.98 & 79.99 & 0.48 \\
7 & 1.20 & 106.71 & 0.70 & 0.70 & 72.06 & 0.54 & 1.00 & 82.22 & 1.12 \\
\hline
\end{tabular}

reductions of droplets at $15 \mathrm{~V}$ for deionized water and $0.1 \mathrm{M} \mathrm{KCl}$ and $70 \mathrm{~V}$ for PCR buffer, respectively. From Fig. 6(b), the contact angle of the deionized water droplet is significantly reduced from $120^{\circ} / 120^{\circ}$ to $115^{\circ} / 90^{\circ}$ on the top wall/bottom wall of a microchannel without $1 \mathrm{cSt}$ silicone oil. The deionized water droplet is seen to evaporate at $200 \mathrm{~V}$.

For $0.1 \mathrm{M} \mathrm{KCl}$ droplets, the contact angle changes from $120^{\circ} / 120^{\circ}$ to $117^{\circ} / 95^{\circ}$ on the top wall/bottom wall without 1cSt silicone oil, as shown in Fig 6(c), and the droplet evaporates at a low voltage of $20 \mathrm{~V}$.

For the PCR buffer droplet, a significant contact angle change happens at $70 \mathrm{~V}$, as shown in Fig. 6(d). The characteristics of the PCR droplet are greatly different from those of deionized water and $0.1 \mathrm{M} \mathrm{KCl}$ droplets since the contact angle changes from $68^{\circ} / 68^{\circ}$ to $63^{\circ} / 62^{\circ}$ and the droplet evaporates at $150 \mathrm{~V}$.

The result of contact angle reduction is summarized in Table 5. The contact angles of droplets on silicone oil decrease by $3^{\circ} / 2^{\circ}, 4^{\circ} / 5^{\circ}$, and $1^{\circ} / 3^{\circ}$ on the top wall/bottom wall for deionized water, $0.1 \mathrm{M} \mathrm{KCl}$, and PCR buffer, respectively. Thus, silicone oil causes 


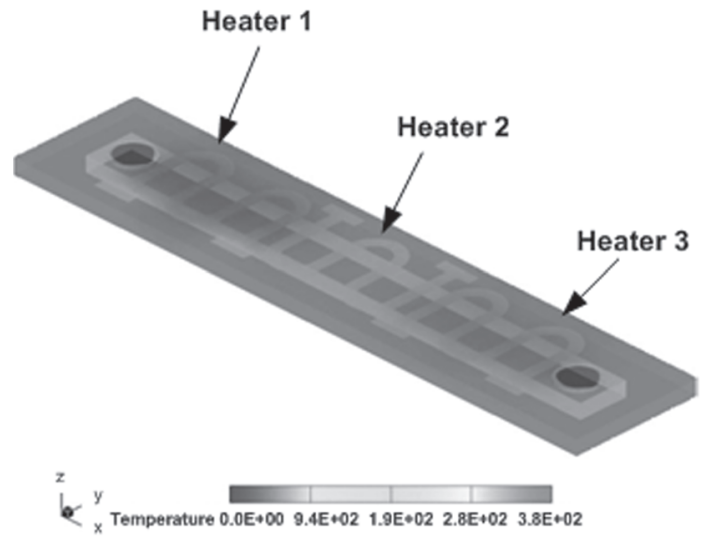

(a)

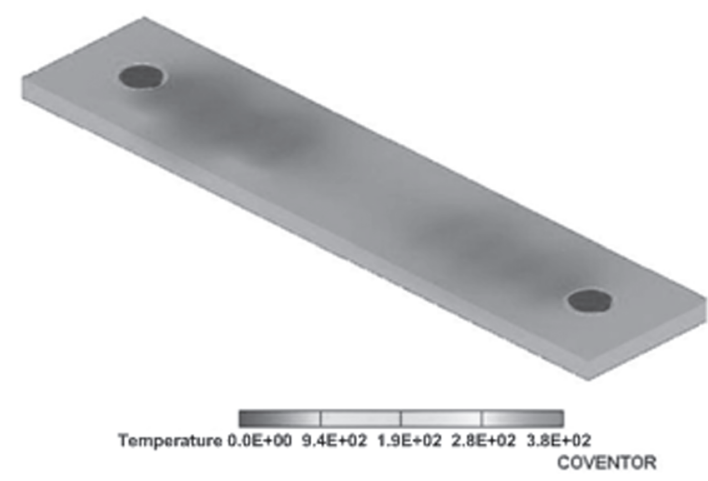

(b)

Fig. 5. Temperature distribution of (a) microheaters (by transparent view through microchannel, inlet, and outlet) and (b) PDMS microchannel of a droplet-based PCR.

Table 2

First set of applied voltages at PCR temperatures: comparison between experimental and simulation data.

\begin{tabular}{|c|c|c|c|c|}
\hline \multirow[b]{2}{*}{ Microheater } & \multirow[b]{2}{*}{$\begin{array}{l}\text { Applied voltage } \\
\text { (V) }\end{array}$} & \multicolumn{2}{|c|}{ Simulation } & \multirow{2}{*}{$\begin{array}{c}\text { Experiment } \\
\text { Microheater } \\
\left(T_{\max },{ }^{\circ} \mathrm{C}\right)\end{array}$} \\
\hline & & $\begin{array}{c}\text { Microheater } \\
\left(T_{\max },{ }^{\circ} \mathrm{C}\right)\end{array}$ & $\begin{array}{l}\text { Microchannel } \\
\left(T_{\max },{ }^{\circ} \mathrm{C}\right)\end{array}$ & \\
\hline Heater 1 & 1.11 & 95.17 & 94.70 & 94.29 \\
\hline Heater 2 & 0.56 & 61.10 & 60.62 & 60.37 \\
\hline Heater 3 & 0.95 & 77.64 & 77.16 & 76.93 \\
\hline
\end{tabular}

Table 3

Second set of applied voltages at PCR temperatures: comparison between experimental and simulation data.

\begin{tabular}{ccccc}
\hline \multirow{2}{*}{ Microheater } & $\begin{array}{c}\text { Applied voltage } \\
(\mathrm{V})\end{array}$ & $\begin{array}{c}\text { Microheater } \\
\left(T_{\max },{ }^{\circ} \mathrm{C}\right)\end{array}$ & $\begin{array}{c}\text { Microchannel } \\
\left(T_{\max },{ }^{\circ} \mathrm{C}\right)\end{array}$ & $\begin{array}{c}\text { Experiment } \\
\text { Microheater } \\
\left(T_{\max },{ }^{\circ} \mathrm{C}\right)\end{array}$ \\
\hline Heater 1 & 1.08 & 91.25 & 90.87 & 90.34 \\
Heater 2 & 0.57 & 62.03 & 61.63 & 61.16 \\
Heater 3 & 0.91 & 72.67 & 72.29 & 72.20 \\
\hline
\end{tabular}

Table 4

Third set of applied voltages at PCR temperatures: comparison between experimental and simulation data.

\begin{tabular}{ccccc}
\hline \multirow{2}{*}{ Microheater } & $\begin{array}{c}\text { Applied voltage } \\
(\mathrm{V})\end{array}$ & $\begin{array}{c}\text { Microheater } \\
\left(T_{\max },{ }^{\circ} \mathrm{C}\right)\end{array}$ & $\begin{array}{c}\text { Microchannel } \\
\left(T_{\max },{ }^{\circ} \mathrm{C}\right)\end{array}$ & $\begin{array}{c}\text { Experiment } \\
\text { Microheater } \\
\left(T_{\max },{ }^{\circ} \mathrm{C}\right)\end{array}$ \\
\hline Heater 1 & 1.16 & 101.46 & 100.98 & 100.60 \\
Heater 2 & 0.65 & 67.93 & 67.53 & 67.47 \\
Heater 3 & 0.98 & 79.99 & 79.50 & 79.30 \\
\hline
\end{tabular}




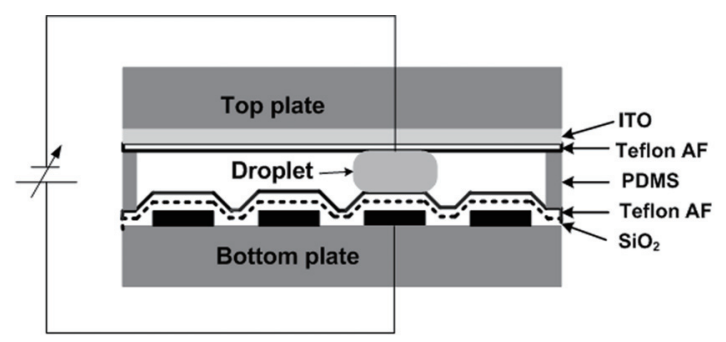

(a)

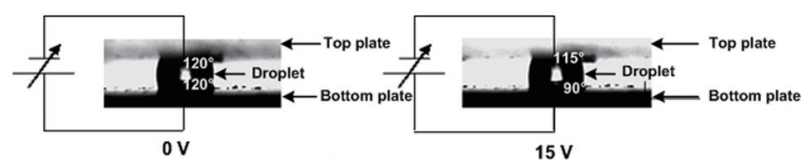

(b)

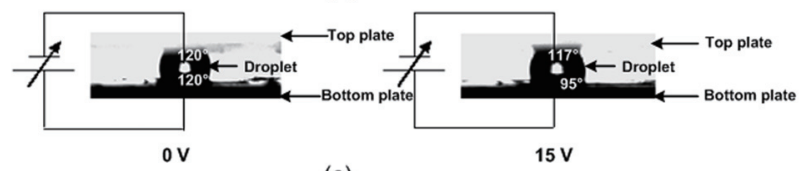

(c)

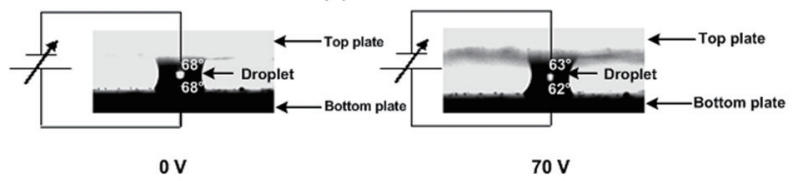

(d)

Fig. 6. Relationship between voltage drop across the dielectric layer and contact angle. (a) Schematics of experimental setup. (b) Images of deionized droplet. (c) Images of $0.1 \mathrm{M} \mathrm{KCl}$ solution. (d) Images of PCR buffer.

Table 5

Effect of medium on contact angle of droplets in PCR microchannel.

\begin{tabular}{lcccccc}
\hline Droplet type & \multicolumn{2}{c}{ Deionized water } & \multicolumn{2}{c}{$0.1 \mathrm{M} \mathrm{KCl}$} & \multicolumn{2}{c}{ PCR buffer } \\
\hline Voltage (V) & 0 & 15 & 0 & 15 & 0 & 70 \\
\hline $\begin{array}{l}\text { Contact angle on top wall/ } \\
\text { bottom wall } \\
\text { (only air in microchannel) }\end{array}$ & $120^{\circ} / 120^{\circ}$ & $115^{\circ} / 90^{\circ}$ & $120^{\circ} / 120^{\circ}$ & $117^{\circ} / 95^{\circ}$ & $68^{\circ} / 68^{\circ}$ & $63^{\circ} / 62^{\circ}$ \\
$\begin{array}{l}\text { Contact angle on top wall/ } \\
\text { bottom wall } \\
\text { (silicone oil at bottom of } \\
\text { microchannel) }\end{array}$ & $120^{\circ} / 120^{\circ}$ & $112^{\circ} / 98^{\circ}$ & $120^{\circ} / 120^{\circ}$ & $113^{\circ} / 90^{\circ}$ & $68^{\circ} / 68^{\circ}$ & $62^{\circ} / 59^{\circ}$ \\
\hline
\end{tabular}

considerable contact angle reductions. Additionally, a voltage of more than $800 \mathrm{~V}$ can be applied to a deionized water droplet without causing evaporation. Moreover, the droplets of $0.1 \mathrm{M} \mathrm{KCl}$ and PCR buffer reagent evaporate on silicone oil at higher voltages of 200 and $450 \mathrm{~V}$, respectively. The result of droplet evaporation is listed in Table 6. 
Table 6

Effect of medium on evaporation voltage of droplets in PCR microchannel.

\begin{tabular}{lccc}
\hline Droplet type & Deionized water & $0.1 \mathrm{M} \mathrm{KCl}$ & PCR buffer \\
\hline $\begin{array}{l}\text { Applied voltage for evaporation } \\
\text { on top wall/bottom wall (V) } \\
\text { (only air in microchannel) }\end{array}$ & 200 & 20 & 150 \\
$\begin{array}{l}\text { Applied voltage for evaporation } \\
\text { on top wall/bottom wall (V) } \\
\text { (silicone oil at bottom of microchannel) }\end{array}$ & $>800$ & 200 & 450 \\
\hline
\end{tabular}

Although insulating layers on control electrodes should prevent electrical conduction under the applied voltage, there is still some leakage current passing through the droplet that causes Joule heating, because very thin sputtered silicon dioxide and spincoated Teflon are far from being perfect insulators. Joule heating causes the droplet temperature to increase and evaporation to occur. Joule heating through a droplet is directly dependent on the resistance of the fluid. The resistances of $0.1 \mathrm{M} \mathrm{KCl}$ solution, PCR buffer, and deionized water are low, medium, and high respectively. Thus, the corresponding Joule heating for $0.1 \mathrm{M} \mathrm{KCl}$, PCR buffer, and deionized water will be high, medium and low, respectively. This explains the results that the evaporation voltages of $0.1 \mathrm{M} \mathrm{KCl}$, PCR buffer, and deionized water are low (20 V), medium (150 V), and high $(200 \mathrm{~V})$, respectively.

The same droplet on silicone oil evaporates at a temperature higher than that in air because droplets on silicone oil are not in direct contact with the control electrode. As a result, the current will have to pass through silicone oil instead. Since the electrical resistance of silicone oil is considerably higher than that of deionized water, $0.1 \mathrm{M} \mathrm{KCl}$, and PCR buffer, a lower conduction current and less Joule heating occur at a given applied voltage. Thus, the temperature of a droplet on silicone oil will be significantly lower than that in air, and a higher applied voltage can be applied to a droplet on silicone oil without evaporation.

\subsubsection{Microheater analysis}

A calibration measurement for the $\mathrm{Cr} / \mathrm{Au}$ temperature sensor has been conducted and a linear temperature dependence of $\mathrm{Cr} / \mathrm{Au}$ resistance, $R(\Omega)=0.6339 T\left({ }^{\circ} \mathrm{C}\right)+465.73$, is obtained. The temperature measurements of three microheaters under different applied voltages are compared with the simulation, as shown in Tables $2-4$. It can be seen that the data obtained from the experiment is close to that obtained from the simulation. The difference between the experimental and simulation data is less than $1^{\circ} \mathrm{C}$. Table 3 shows the applied voltages that produce the temperature in accordance with the PCR process. Although the temperature distribution of the PCR microchannel is fairly uniform in each temperature zone from the simulation, the temperature measured using the temperature sensor is lower than the simulation data. The error between the simulation and experimental data for the temperature of the microheater ranges from 0.65 to $1.42 \%$. 


\subsubsection{PCR results}

The PCR products obtained from the droplet-based PCR chip have been analyzed by gel electrophoresis. The separation of DNA bands of the PCR product is visualized using a UV transilluminator and compared with a $100 \mathrm{bp}$ DNA marker for the determination of DNA size. From the comparison with a 100 bp DNA marker, the DNA band is clearly visible, and thus DNA amplification by the droplet-based PCR chip has been successful.

\section{Conclusion}

In conclusion, a droplet-based PCR chip with an integrated EWOD device has been designed, fabricated, and characterized with silicone oil applied at the bottom of the microchannel. The EWOD configuration and serpentine-shape microheaters have been designed on the basis of theoretical calculation and finite element (FEM) simulation. The minimum voltage for contact angle change, driving voltage for transporting a droplet, and channel gap for splitting a droplet in the system can be calculated. Thermal simulation results show that a room-temperature operation of the PCR microchannel with no applied voltage to microheaters can be achieved by filling the bottom of the microchannel with silicone oil. The optimized applied voltages of three microheaters for the temperature of PCR are $1.08,0.57$, and $0.91 \mathrm{~V}$. In addition, the fairly uniform temperature distributions confirm that the shapes of the microchannel and microheaters are properly designed.

A PCR chip has been successfully fabricated and characterized by contact angle analysis, evaporation testing, microheater measurement, and PCR experiment with a specific DNA. The experimental results show that the contact angle reduction and temperature of evaporation are better in silicone oil than in air. The results indicate that silicone oil application in the microchannel is an effective way of improving PCR performance. Additionally, the temperatures of three microheaters are measured using a temperature sensor. The error between the simulation and experimental data for the temperatures of the microheaters approximately ranges from 0.65 to $1.42 \%$. Moreover, a PCR experiment in the droplet-based PCR chip confirms a successful DNA amplification.

\section{Acknowledgment}

This work is supported by Nanoelectronics MEMS Laboratory, National Science and Technology Developent Agency (NSTDA).

\section{References}

1 C. Zhang, J. Xu, W. Ma and W. Zheng: Biotechnol. Adv. 24 (2006) 243.

2 Z. Q. Niu, W. Y. Chen, S. Y. Shao, X. Y. Jia and W. P. Zhang: J. Micromech. Microeng. 16 (2006) 425.

3 P. Neuzil, J. Pipper and T. M. Hsieh: Mol. Biosyst. 2 (2006) 292.

4 P. Neuzil, C. Zhang, J. Pipper, S. Oh and L. Zhuo: Nucleic Acids Res. 34 (2006) e77. 
5 B. C. Giordano, J. Ferrance, S. Swedberg, A. F. R. Huhmur and J. P. Landers: Anal. Biochem. $291(2001) 124$.

6 D.-J. Yao and J.-R. Chen: IEEE MEMS Istanbul, January 22-26 (2006) p. 398.

7 S. Li and S. Chen: J. Manuf. Processes 6 (2004) 81.

8 J. Xiaoyu, N. Zhiqiang, C. Wenyuan and Z. Weiping: Electron. Lett. 41 (2005) 890.

9 S. Li, D. Y. Fozdar, M. F. Ali, H. Li, D. Shao, D. M. Vykoukal, P. N. Floriano, M. Olsen, J. T. McDevitt, P. R. C. Gascoyne and S. Chen: J. Microelectromech. Syst. 15 (2006) 223.

10 W. Wang, Z.-X. Li, R. Luo, S.-H. Lu, A.-D. Xu and Y.-J. Yang: J. Micromech. Microeng. 15 (2005) 1369.

11 M. Bu, T. Melvin, G. Ensell, J. S. Wilkinson and A. G. R. Evans: J. Micromech. Microeng. 13 (2003) S125.

12 W. Dai and Y.-P. Zhao: Int. J. Nonlinear Sciences and Numerical Simulation 8 (2007) 519.

13 L. Hu, G. Gruner, J. Gong, C.-J. Kim and B. Hornbostel: Appl. Phys. Lett. 90 (2007) 093124.

14 J. Berthier, P. Dubois, P. Clementz, P. Claustre, C. Peponnet and Y. Fouillet: Sens. Actuators, A 134 (2007) 471.

15 S. W. Walker and B. Shapiro: J. Microelectromech. Syst. 15 (2006) 986.

16 J. Lienemann, A. Greiner and J. G. Korvink: IEEE Trans. Computer-Aided Design of Integrated Circuits and Systems 25 (2006) 234.

17 T. B. Jones: J. Microelectromech. Microeng. 15 (2005) 1184.

18 F. Mugele and J.-C. Baret: J. Phys. Condens Matter 17 (2005) R705.

19 U.-C. Yi and C.-J. Kim: J. Micromech. Microeng. 16 (2006) 2053.

20 M. G. Pollack and R. G. Fair: Appl. Phys. Lett. 77 (2000) 1725.

21 Y.-H. Chang, G.-B. Lee, F.-C. Huang, Y.-Y. Chen and J.-L. Lin: Biomed. Microdevices 8 (2006) 215.

22 V. Srinivasan, V. K. Pamula and R. B. Fair: Lab. Chip 4 (2004) 310.

23 Y. Zhao and S. K. Cho: Lab. Chip 6 (2006) 137.

24 D. Klaitabtim, T. Lomas, A. Wisitsora-at and A. Tuantranont: 2004 IEEE Region 10 Conference Tencon, November 21-24 (2) (2004) p. 450.

25 H. Moon, S. K. Cho, R. L. Garrell and C.-J. Kim: Appl. Phys. 92 (2002) 4080.

26 S. K. Cho, H. Moon, J. Fowler and C.-J. Kim: ASME International Mechanical Engineering Congress and Exposition, New York, November 1-16 (2001) p. 1.

27 S. K. Cho, H. Moon, J. Fowler and C.-J. Kim: J. Microelectromech. Syst. 12 (2003) 1. 